(1)(1).2621-1

$2 C-60$

\title{
OPERATIONAL, COST, AND TECHNICAL STUDY OF LARGE WINDPOWER SYSTEMS INTEGRATED WITH AN EXISTING ELECTRIC UTILITY
}

Progress Report.

for Period May 1, 1975-October 31, 1975

R. K. Swanson, R. T. Smith, et al

Southwest Research Institute 8500 Culebra Road

San Antonio, Texas 78284

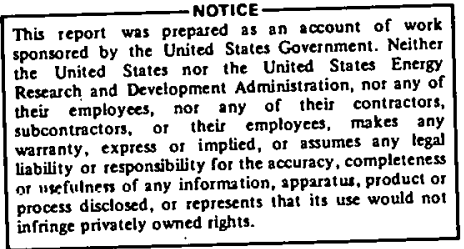

Prepared for

THE U. S. ENERGY RESEARCH AND DEVELOPMENT ADMINISTRATION UNDER CONTRACT NO. E(11-1)-2621

November 197.5

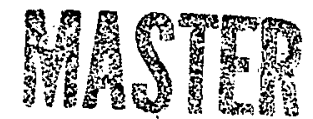

Approved:

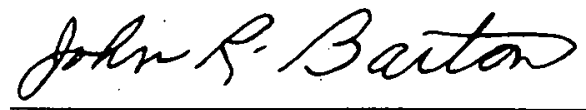

John R. Barton, Vice President

Instrumentation Research Division 


\section{DISCLAIMER}

This report was prepared as an account of work sponsored by an agency of the United States Government. Neither the United States Government nor any agency Thereof, nor any of their employees, makes any warranty, express or implied, or assumes any legal liability or responsibility for the accuracy, completeness, or usefulness of any information, apparatus, product, or process disclosed, or represents that its use would not infringe privately owned rights. Reference herein to any specific commercial product, process, or service by trade name, trademark, manufacturer, or otherwise does not necessarily constitute or imply its endorsement, recommendation, or favoring by the United States Government or any agency thereof. The views and opinions of authors expressed herein do not necessarily state or reflect those of the United States Government or any agency thereof. 


\section{DISCLAIMER}

Portions of this document may be illegible in electronic image products. Images are produced from the best available original document. 


\section{NOTICE}

This report was prepared as an account of work sponsored by the United States Government. Neither the United States nor the United States Energy Research and Development Administration, nor any of their employees, nor any of their contractors, subcontractors, or their employees, makes any warranty, express or implied, or assumes any legal liability or responsibility for the accuracy, completeness, or usefulness of any information, apparatus, product or process disclosed or represents that its use would not infringe privately owned rights. 


\section{ABSTRACT}

This report presents the progress during the period 1 May 1975 to 31 October 1975 on a study of the windpower potential in the Texas Panhandle, with particular reference to the integration of wind-generated electrical power into an existing electric utility system.

Using data from 17 wind stations in the region, it has been calculated that the specific energy output of the region can be upwards of $0.65 \mathrm{kwh}$ per rated $\mathrm{kw}$ per hour, averaged over a yearly period. The analysis utilizes realistic wind generation system performance at three different rated wind speeds: $8,10.7$ and $13.4 \mathrm{~m} / \mathrm{s}$. Four different tower heights are assumed: $30,46,61$ and $76 \mathrm{~m}$.

A transient thermodynamic model of a compressed-air storage sub-system has been created and analyzed for operating conditions compatible with the utility network demand schedules. Both $100 \mathrm{mw}$ and $20 \mathrm{mw}$ nominal ratings have been considered. A complete energy balance has been performed for a subsystem consisting of motor-generatorcompressor combination with intercoolers, aftercoolers, throttling, dehumidification, air cavern storage and a fuel-fired gas turbine.

Typical utility technical and operational requirements for windgeneration plants have been established. These indicate that remote unattended operation at distribution or possibly sub-transmission levels is desirable. In addition to fail-safe operation, controls must limit voltage fluctuations caused by starting, stopping, resynchronizing, and wind torque pulsations. Provisions for efficient maintainability are of paramount importance. A detailed electrical system study should be carried out for each proposed interface.

A study of institutional considerations for windpower shows that Texas has an unusually favorable regulatory climate. No state regulatory agencies have direct cognizance of utility plant construction. In addition Federal Power Commission and Security and Exchange Commission guidlines would not be restrictive upon windpower development. The most restrictive requirements for the utilities are those of good business practice in accounting to stockholders and other financial sources. 
TABLE OF CONTENTS

$\begin{array}{llr} & & \frac{\text { Page }}{r} \\ \text { I. } & \text { GENERAL } & 3 \\ \text { II. } & \text { WIND ASSESSMENT TASK } & 14 \\ \text { III. } & \text { ENERGY STORAGE ASSESSMENT TASK } \\ \text { IV. } & \text { COST GOAL DE TERMINA TION TASK } \\ \text { V. } & \text { TECHNICAL AND OPERA TIONAL REQUIREMENTS TASK } \\ \text { VI. INSTITUTIONAL CONSIDERATIONS TASK } & 20\end{array}$


I. GENERAL

The objective of this program is to explore the feasibility of the use of windpower generating systems as supplemental energy sources on existing electric utilities in the time frame of the next two decades. Specifically the study is centered upon the geographical region se rved by Southwestern Public Service Co., an investor owned utility headquartered in Amarillo, Texas. The region includes most of the Panhandle of Texas, the Panhandle of Oklahoma, parts of eastern New Mexico and some communities in Southwest Kansas. The present capacity of the utility is about $2000 \mathrm{MW}$. Of prime importance, this region exhibits the highest wind energy potential of any area of comparable size in the Continental U. S.

A study of this type must take many factors into consideration: technical, operational, institutional, and economic. Accordingly, a multi-faceted program has been organized to address each of these important areas. A project team reflecting a broad base in background, capability and interest has been formed. Major subcontractors are:

1. Texas Tech University; Lubbock, Texas

2. Southwestern Public Service Co., Amarillo, Texas

3. Boeing Vertol Co., Philadelphia, Pa.

Several consultants have been retained to provide expertise in certain areas and they are: Mr. H. O. Hodson, recently retired Vice President of Engineering, Southwestern Public Service Co.; Dr. Earl H. Gilmore, Head, Department of Physical Sciences, Amarillo College; and Dr. Vaughn Nelson, Head, Department of Physics, West Texas State University.

Principal members of the project team are as follows:

Southwest Research Institute

Mr. Robert K. Swanson, Project Manager

Dr. Richard T. Smith, Principal Investigator

Mr. Craig C. Johnson

Texas Tech University

Dr. James H. Lawrence, Jr.

Dr. Duane P. Jordan

Dr. G. S. Kirby (now with Tulane University) 
Southwestern Public Service Co.

Mr. Cleon Ligon

Boeing Vertol Company

Mr. Wayne Wiesner (proposed)

Specific major tasks with assigned responsibilities are as follows:

1. Wind Assessment - Texas Tech

2. Energy Storage Assessment - Texas Tech, SwPSC, SwRI

3. Cost Goal Determination - SwRI SwPSC

4. Technical and Operational Requirements - SwRI, SwPSC

5. Institutional Considerations - SwRI, SwPSC

6. WGS Cost Estimates - Boeing Vertol

A final task is to assimilate and integrate the results of the above efforts with the view of preparing definitive recommendations for further work.

At this point significant progress has been made on Tasks 1, 2, 4 and 5 . Task 3 is just getting underway. Task 6 has not as yet been initiated because of a long series of delays in subcontractual negotiations and necessary approvals. The delay of this latter task, up to now at least, should not have significant deleterious impact upon the overall program. However, further delay should be cause for consideration of re-structuring, modifying or deleting this task. Except as noted above, no problems are foreseen in fulfilling the objectives of this work within the schedule and fund limitations.

During the reporting period Mr. Swanson devoted $18 \%$ of his time to this project; Dr. Smith, $62 \%$. This approximate level of loading will be continued.

Specific progress and status of ongoing effort for each of the major tasks is presented below. 


\section{WIND ASSESSMENT TASK}

This major task is being performed by Texas Tech University under subcontract. In addition, Dr. Earl Gilmore of Amarillo College and Dr. Vaughn Nelson of West Texas State University are serving as consultants for the wind measurement subtask. The effort is broken down into the following subtasks:

Subtask 1 Wind Energy Distribution - estimate the distribution of kinetic energy of the wind per unit vertical area, at various heights above ground level, throughout the region.

Subtask 2 Potential Electrical Energy Generation - estimate the distribution of potential aeromotive electrical energy extraction rates, based on selected wind turbine performance characteristics, throughout the region.

Subtask 3 Practical Windpower Utilization - estimate the practical windpower utilization rate based on various specifications of unit spacings and groupings at specified general locations throughout the region.

Subtask 4 On-Site Wind Measurement - to make wind measurements at two selected sites, one near Carlsbad, New Mexico and another near Lake Meredith, Texas.

Subtasks 1 and 2

Data Base

The electrical distribution system of the Southwestern Public Service Company (SwPSC) of Amarillo, Texas extends from near Carlsbad, New Mexico through the Texas and Oklahoma panhandles to the southern border of Kansas. There are 17 locations scattered throughout the system for which detailed wind records are available. The stations used in this assessment are shown in Table $I$.

The periods of record were chosen as the most recent and reliable available.

\section{Data Reduction}

For each station, the following data reduction scheme has been employed. 
TABLE I

Wind Data Stations

\section{Name}

1. Dodge City, Kansas

2. Garden City, Kansas

3. Carlsbad, New Mexico

4. Clayton, New Mexico

5. Clovis/Cannon, New Mexico

6. Hobbs, New Mexico

7. Roswell, New Mexico

8. Amarillo, Texas

9. Big Spring/Webb, Texas

10. Childress, Texas

11. Dalhart, Texas

12. Lubbock, Texas

13. Midland, Texas

14. Wink, Texas

15. Altus, Oklahoma

16. Gage, Oklahoma

17. Hobart, Oklahoma
Number

13985

23064

93033

23051

23008

93034

23043

23047

23005

23007

93042

23042

23023

23040

13092

13975

93986
Period of Record Used $01 / 64-12 / 73$

$01 / 50-12 / 54$

$01 / 50-12 / 54$

$01 / 64-12 / 72$

$01 / 61-12 / 70$

$01 / 50-12 / 54$

$01 / 61-12 / 68$

$01 / 62-12 / 72$

$01 / 66-12 / 70$

$01 / 50-12 / 54$

$01 / 50-12 / 54$

$01 / 49-12 / 72$

$01 / 60-12 / 72$

$01 / 50-12 / 54$

$01 / 61-12 / 70$

$01 / 50-12 / 54$

$01 / 50-12 / 54$ 
1. Windspeed/Duration. The hourly wind speed values are segregated into two groups: the day period from 0700 to 1800 hours and the night period from 1900 to 0600 hours. The wind speeds are compiled in terms of percent duration for which a given windspeed was equaled or exceeded. Because the wind records report integer values of wind speed in knots, that unit of measurement is used in this report. A sample of the speed/duration compilation is presented in Figure 1. As demonstrated in the Figure, the distribution of wind during the night period is much different from that of the day period, the speed being substantially less at night. These data are tabulatcd for each station at the anemomete $r$ height, averaged over the period of record.

2. Height Extrapolation. Wind speed normally increases with height as a function of both atmospheric lapse rate and surface roughness. Empirical investigations of the relationship of wind speed with the height have demonstrated that the vertical profile data can be adequately treated with only two divisions of atmospheric stability conditions, namely stable and unstable. [ 1 The former consists of inversion, isothermal, and adiabatic conditions described by the power law relation, [2]

$$
U_{S}=U_{r, s}\left(h / h_{r}\right)^{a} \text { for stable conditions. }
$$

The latter condition is well described by the logarithmic relation, [3]

$$
U_{u}=U_{r, u} \frac{\ln \left(h / z_{o}\right)}{\ln \left(h_{r} / z_{o}\right)} \text { for unstable conditions }
$$

where

$$
\begin{aligned}
\mathrm{h}= & \text { height above ground } \\
\mathrm{U} & =\text { wind speed } \\
\mathrm{z}_{\mathrm{O}}= & \text { characteristic roughness length } \\
\mathrm{a} & =\text { exponent, a function of lapse rate and wind speed } \\
\mathrm{r} & =\text { subscript, refers to reference anemoneter } \\
& \text { at height } \mathrm{h}_{\mathrm{r}} \\
\mathrm{s}= & \text { subscript, refers to stable conditions } \\
\mathrm{u}= & \text { subscript, refers to unstable conditions }
\end{aligned}
$$

In the SwPSC region, the atmospheric conditions are unstable 70 percent of the time on an annual basis [4] Virtually all of the stable lapse rates occur at night, but the degree of stability is minimal. The annual mean lapse rate in Amarillo, Texas at 6 a.m., CST, is only 0.86 degrees centigrade per 100 meters. Thus, the logarithmic wind speed variation with height, equation (2) above, is used for the day period. The night period wind speed extrapolation to various heights is performed using an average of the two expressions (1) and (2) weighted on frequency of occurrence of stable conditions.

[1] Numbers in brackets refer to references listed at the end of this section. 


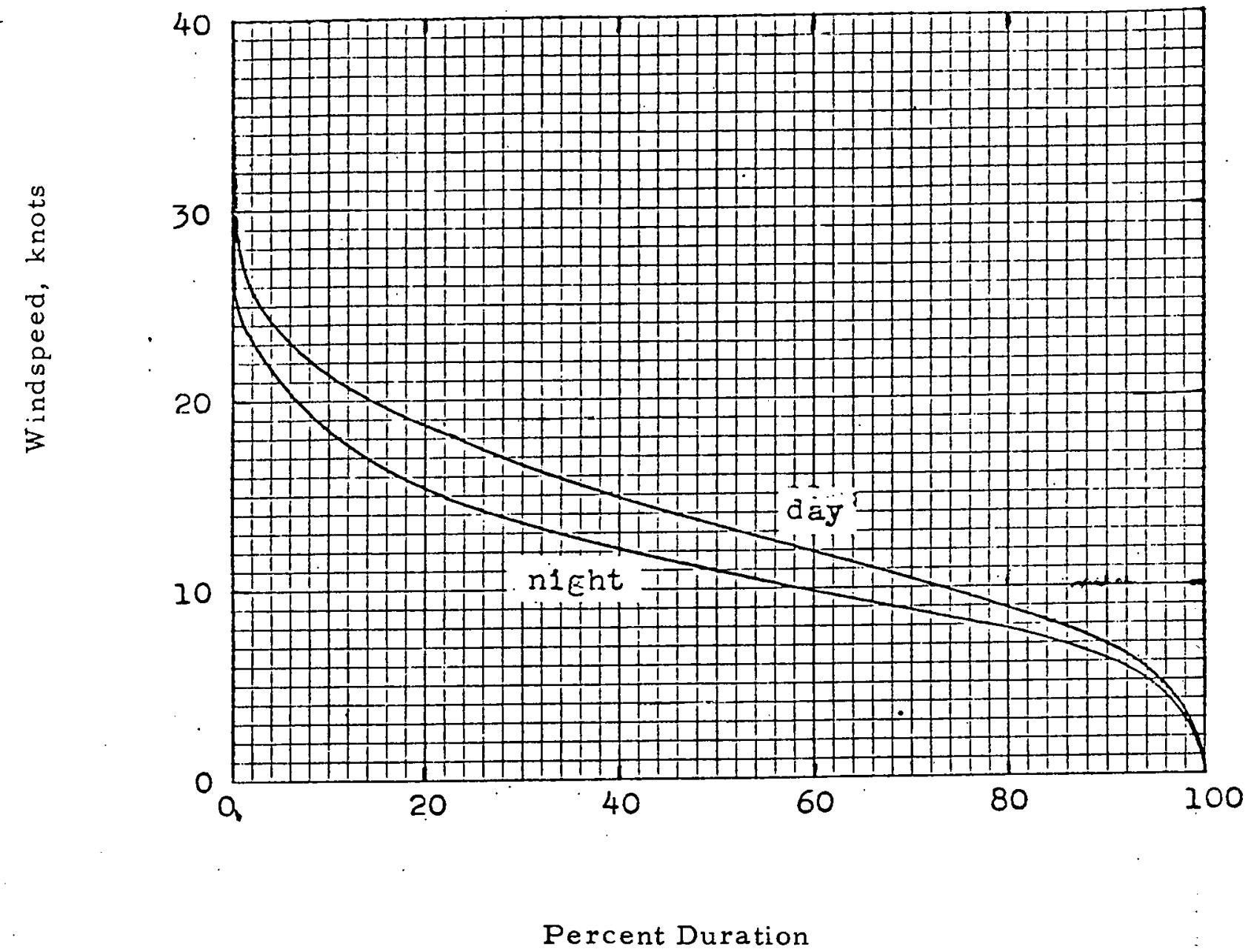

FIGURE 1. WINDSPEED/PERCENT DURATION CURVE FOR AMARILLO, TEXAS. $1962-1972$ 
For the night, the wind speed is given by,

$$
\mathrm{U}=0.7 \mathrm{U}_{\mathrm{u}}+0.3 \mathrm{U}_{\mathrm{s}}
$$

The characteristic roughness. length $z_{0}$ is an empirical constant which should be locally evaluated because it is a function of the local terrain geometry and ground cover. However, the only long-term wind data in the region at two significantly different heights at the same location is from the National Weather Service Stations at Lubbock Regional Airport. The Lubbock anemometer was at a height of 68 feet from June, 1950 to September, 1965, when it was lowered to 25 feet and placed on a tower adjacent to the airport runway. The annual wind speed average at the 68 foot height is $8.55 \mathrm{~m} / \mathrm{s}$ and $7.67 \mathrm{~m} / \mathrm{s}$ at the 25 foot height. These data are fit by the logarithmic relation (2) for $z_{0} 0.2$ feet which corresponds to a surface govered by long to medium height grasses as computed by other investigators []$_{\text {This roughness parameter }}$ is used for all stations.

The exponent "a" of equation (1) is a function of both wind speed and lapse rate[6] The latter is taken to. be constant at the $6 \mathrm{a} . \mathrm{m}$. average value of 0.18 degrees centigrade per 100 meters. The empirical data of Rijkoort are well fit by the following set of linear equations,

$$
\begin{array}{ll}
a=0.557-0.0316 \mathrm{U}_{\mathrm{r}} & 1 \mathrm{knot} \leq \mathrm{U}_{\mathrm{r}}<11 \mathrm{knots} \\
\mathrm{a}=0.325-0.01 \mathrm{U}_{\mathrm{r}} & 11 \text { knots } \leq \mathrm{U}_{\mathrm{r}}<18 \text { knots } \\
\mathrm{a}=0.15 & \mathrm{U}_{\mathrm{r}} \geq 18 \text { knots }
\end{array}
$$

Wind speeds are extrapolated by these means to heights of $100,150,200$, and 250 feet for each station and tabulated.

3. Wind Power. The kinetic energy flux of the wind is given by

$$
E=\frac{1}{2} \rho \mathrm{U}^{3}
$$

where $\rho$ is the mass density, computed from the perfect gas equation of state using the annual average values of $d r y$ bulb temperature and barometric pressure. By cubing the wind speed, equation (7) is used to compute the so-called power/duration tabulations directly from the speed/duration tables for each of the extrapolation heights. 
4. Electric Energy Potential. A real wind turbine/generator system will deliver substantially less than the theoretical limit of 59 percent. Performance characteristics from existing and project wind turbines, including all losses, have been used to form a set of composite performance curves for machines of 18,24 and $30 \mathrm{mph}$ rated wind speeds. These curves are presented as Figure 2 .

The power in the wind is given by:

$$
P_{W}=\rho \pi D^{2} U^{3} / 8
$$

for a swept area of diameter $\dot{D}$.

The power output from a turbine/generator system can be defined in terms of a mechanical efficiency $\eta$ as

$$
P=\eta P_{W},
$$

and in general $\eta$ is a function of wind speed. At rated yyjnd speed UR, the following relation holds for the rated power output PR.

$$
D=0.875 \sqrt{\frac{\left.\mathrm{PR} / 10^{-6} \mathrm{KW}\right)}{(\mathrm{UR} / \mathrm{mph})^{3}}} \text { feet }
$$

Lct $P^{*}$ be the ratio $P / P R$ and let $U^{*}$ be the ratio $U / U R$. Then by combination of equations (8), (9) and (10),

$$
\eta=0.368 \mathrm{P} * / \mathrm{U} *{ }^{3}
$$

The nondimensional power $P *$ is a function of nondimensional speed $U *$, as seen in Figure 2. The functional form is independent of wind speed, however, as seen in Figure 3, taken from the performance curves and equation (11). Thus, for any designaled turbine gene rator system, the mechanical efficiency is a function only of wind speed according to the following set of equations fit to the data for Figure 3.

$$
\begin{array}{ll}
\eta=0 & 0 \leq \mathrm{U} * \leq 0.5 \\
\eta=2.36(\mathrm{U} *-0.5) & 0.5 \leq \mathrm{U} * \leq 0.6 \\
\eta=0.15-0.225 \sin (1.25 \mathrm{U} *-0.625) & 0.6 \leq \mathrm{U} * \leq 0.9 \\
\eta=0.368+0.07(1-\mathrm{U} *) & 0.9 \leq \mathrm{U} * \leq 1.0 \\
\eta=0.368 \quad \mathrm{U} * \geq 1.0 \text { and } \mathrm{U} \leq 60 \mathrm{mph} &
\end{array}
$$




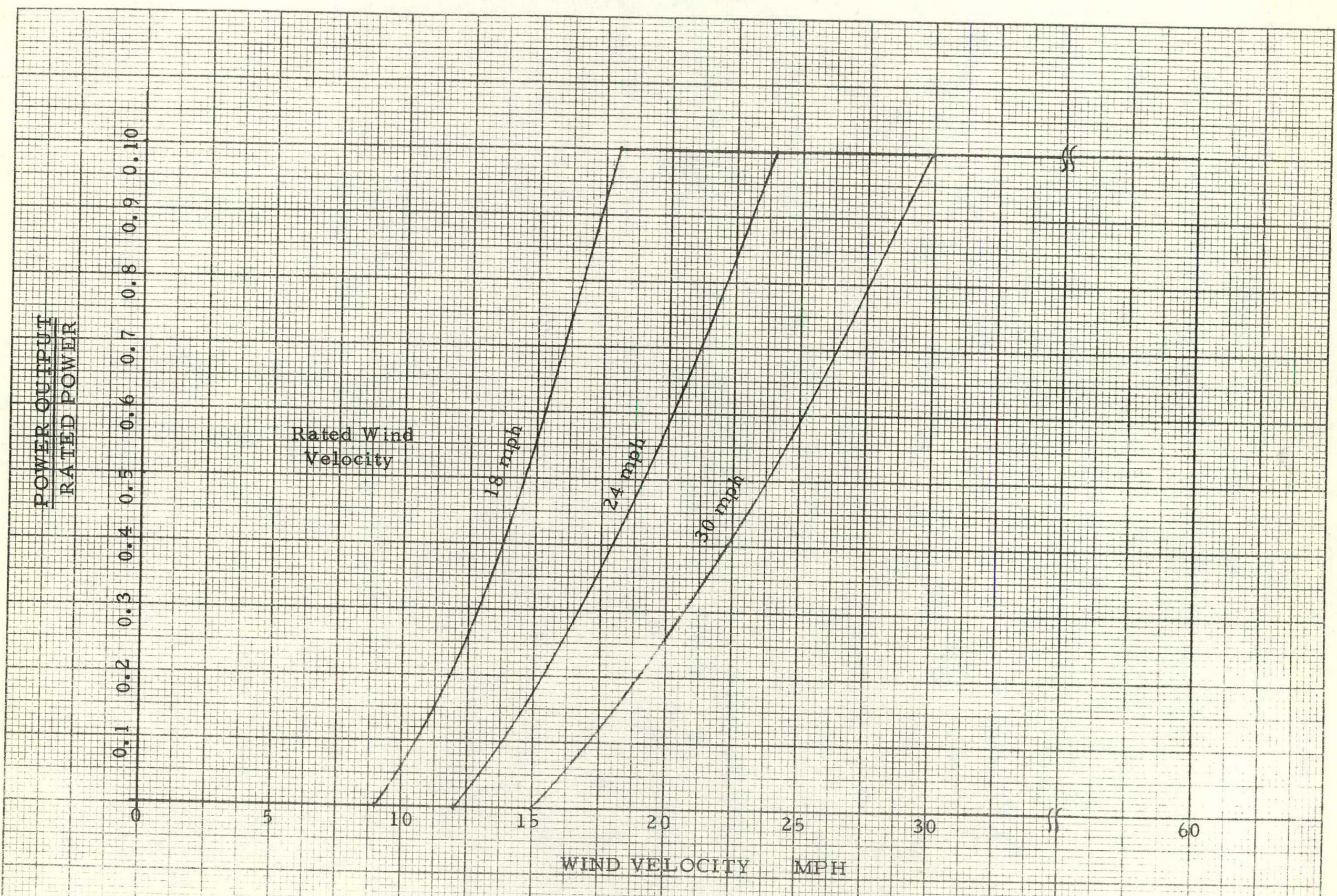

FIGURE 2. WIND TURBINE-GENERA TOR CHARACTERISTIC CURVES. 


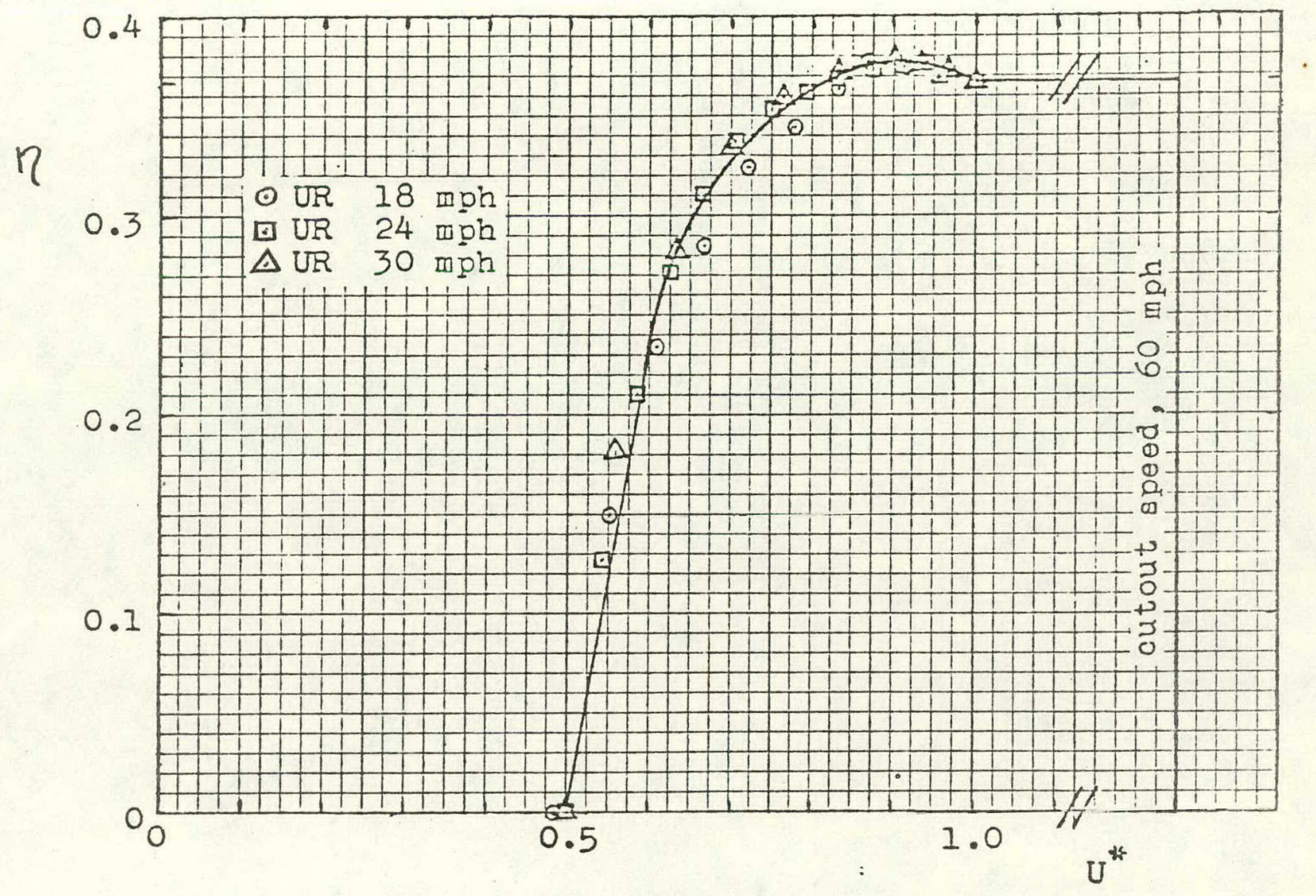

FIGURE 3. EFFICIENCY/WINDSPEED RELATION FROM WIND TURBINE PERFORMANCE CURVES. 
The electrical power/duration tables are computed for each of the three turbine/generator systems by multiplication of the wind power/ duration tables by the mechanical efficiency from Figure 3 (equations 12 through 16). The electrical power/duration tables or curves are numerically integrated using the trapezoid rule approximation to obtain annual average production of electric energy by turbine/generator systems of $1000 \mathrm{kw}$ and $2000 \mathrm{kw}$ rated at 18,24, and $30 \mathrm{mph}$ erected at heights of 100, 150,200 and 250 feet during the day, the night, and the combined period. A sample of some of the results is given in the following table.

TABLE II

ANNUAL ELECTRICAL ENERGY POTENTIAL OF A ONE MEGAWATT TURBINE, JOULES $\times 10^{-13}$

$18 \mathrm{mph} \quad \frac{100 \mathrm{feet}}{24 \mathrm{mph}} \quad \underline{30 \mathrm{mph}} \quad \underline{18 \mathrm{mph}} \quad \underline{200 \mathrm{feet}} \frac{24 \mathrm{mph}}{30 \mathrm{mph}}$

\begin{tabular}{|c|c|c|c|c|c|c|c|}
\hline \multirow{3}{*}{ Midland } & day & 0.896 & 0.579 & 0.313 & 0.992 & 0.704 & 0.430 \\
\hline & night & 0.638 & 0.307 & 0.134 & 0.868 & 0.467 & 0.220 \\
\hline & total & 1.534 & 0.886 & 0.447 & 1.860 & 1.171 & 0.650. \\
\hline \multirow{3}{*}{ Amarillo } & day & 1.177 & 0.865 & 0.563 & 1.265 & 0.991 & 0.703 \\
\hline & night & 1.059 & 0.626 & 0.329 & 1.274 & 0.836 & 0.479 \\
\hline & total. & 2.236 & 1.491 & 0.892 & 2.539 & 1.827 & 1.182 \\
\hline
\end{tabular}

In summary, a procedure for the rational estimation of wind energy based on wind records, empirical wind behavior relations, and turbine/generator performance characteristics has been developed and programmed. All required data for the 17 stations have been collected and processed. This then completes the requirements of subtasks 1 and 2 . Because of the volume, only representative data have been included in this report.

The estimation of practical windpower utilization rates (subtask 3) based on various specifications of unit spacings and groupings has been started. The data generated by subtasks 1 and 2 will be used to accomplish this subtask. This effort is on schedule.

Subtaik 4, which deals with wind measurement at two selected sites, is behind its projected schedule because of instrumentation problems. The instrumentation package has been designed and is shown schematically in Figure 4. 


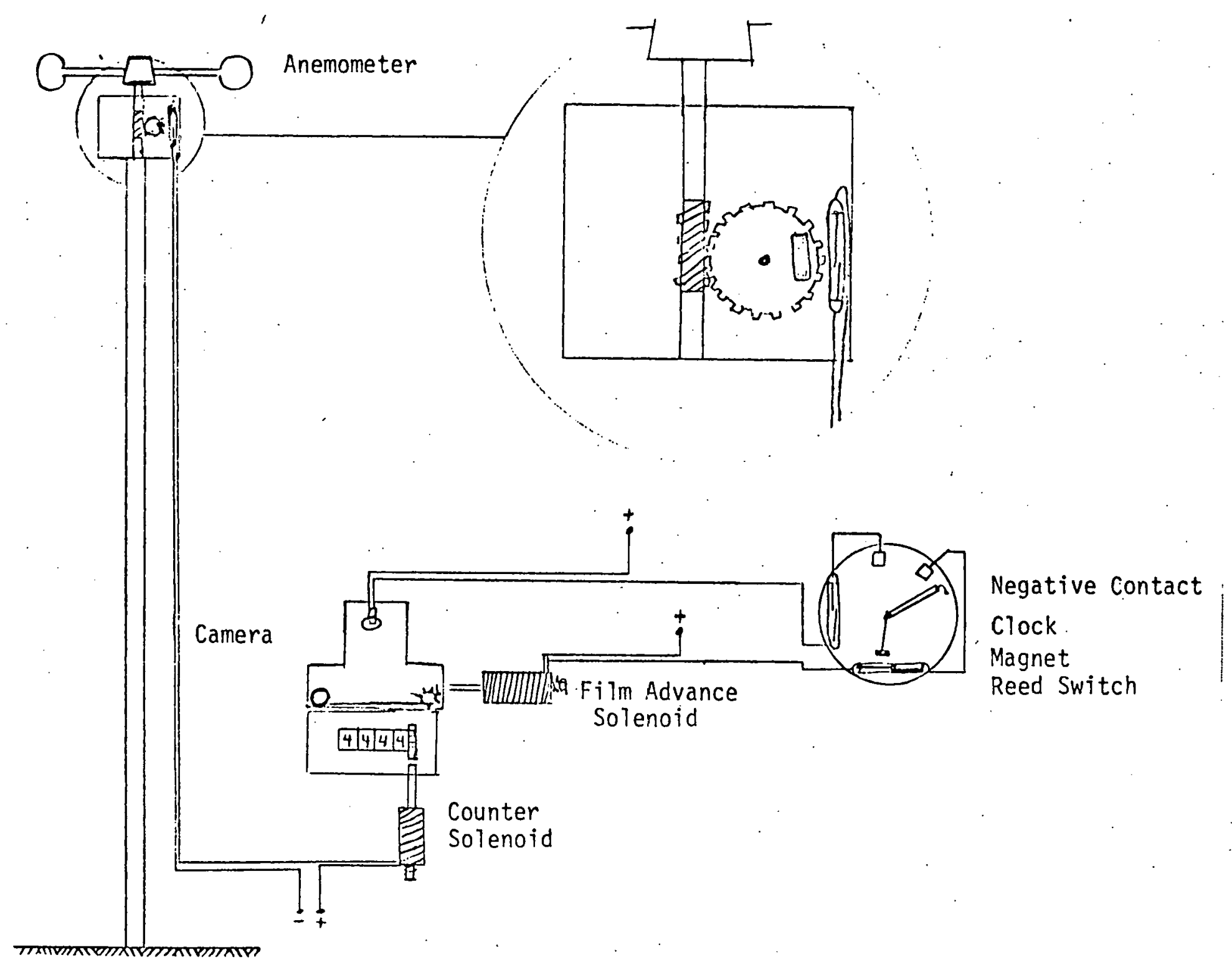

FIGURE 4. INSTR UMENTA TION PACKAGE 
The system has a cup anemometer which gives an electrical pulse for each 0.1 mile that the wind blows. This electrical pulse is used to advance a digital counter. The counter face is then photographed once each hour. The package is powered by two 12 volt automotive type batteries. This gives an integrated wind-time value which can be used to determine a better average wind speed than using hourly readings.

It is expected that on-site measurements using the anemometer instrumentation will get underway during the next quartcr.

\section{REFERENCES}

1. Southwest Research Institute Proposal No. 15-497, "Operational, Cost, and Technical Study of Large Windpower Systems Integrated with Existing Electrical Utilities," 12 July 1974. Appendix B.

2. Thuillier, R. and U. O. Lappe, "Wind and Temperature Profile Characteristics from Observations on a $1400 \mathrm{ft}$. Tower, " J. Applied Meteorology, Vol. 3, pp. 299-306, June, 1964.

3. Davidson, B., et al., Sites for Wind-Power Installations, World Meteorological Organization, Tech. Note No. 63, WMO-No. 156 TP. 75, 1964

4. Hosler, C. R., "Low Level Inversion Frequency in the Contiguous United States," Monthly Weather Review, Vol. 89, pp. 314-339.

5. Nelson, Vaughn and E. Gilmore, "Potential for Wind Generated Power in Texas, "Report NT/8 for Governor's Energy Advisory Council, Oct. 1974.

6. Rijkoort, P. J., "Dependence of Observed Low-Level Wind Shear on Averaging Period and Lapse Rate, "Vertical Wind Shear in the Lower Layers of the Atmosphere, Tech. Note No. 93, WMO-No. 230. TP. 123, 1969 .

7. Johnson, Craig, Southwest Research Institute, letter to G. Kirby, 9 June 1975. 


\section{ENERGY STORAGE ASSESSMENT TASK}

This major task is also being performed by Texas Tech University with significant engineering support from Southwestern Public Service Co. and Southwest Research Institute. This task is comprised of the following subtasks:

Subtask 1 Performance analys is of compressed air storage systems employing an existing, abandoned potash mine. Two systems are to be analyzed: System 1 is a regenerative gas turbine installation in 20 and $100 \mathrm{MW}$ sizes; System 2 is an expander turbine in the $25 \mathrm{MW}$ size range.

Subtask 2 Evaluate Lake Meredith (or other suitable site) as a pumped-hydro storage facility.

Subtask 3 Assess the potential of aquifers and depleted petroleum reservoirs as underground storage facilities for compressed air.

Subtask 4 Prepare preliminary cost estimates for the various storage facilities.

Major effort to date has bcen cuncentrated on Subtask 1, with effort scheduled to get underway on the remaining subtasks during the next quarter.

Under Subtask 1, a transient the rmodynamic mathmatical model has been developed for the System 1 pumped air storage system shown in. Figure 5. The major components of this system are as follows:

1. Two stage, motor driven air compressor with one stage of intercooling.

2. Series of three aftercoolers; the first being an air-to-air heat exchanger; the second, air-to-water; and the third being air-to-refrigerant.

3. Throttling valve.

4. Reheater; refrigerant-to-air.

5. Air storage cavern. (approximate volume: $70 \times 10^{6} \mathrm{ft}^{3}$ )

6. Throttling valve. 


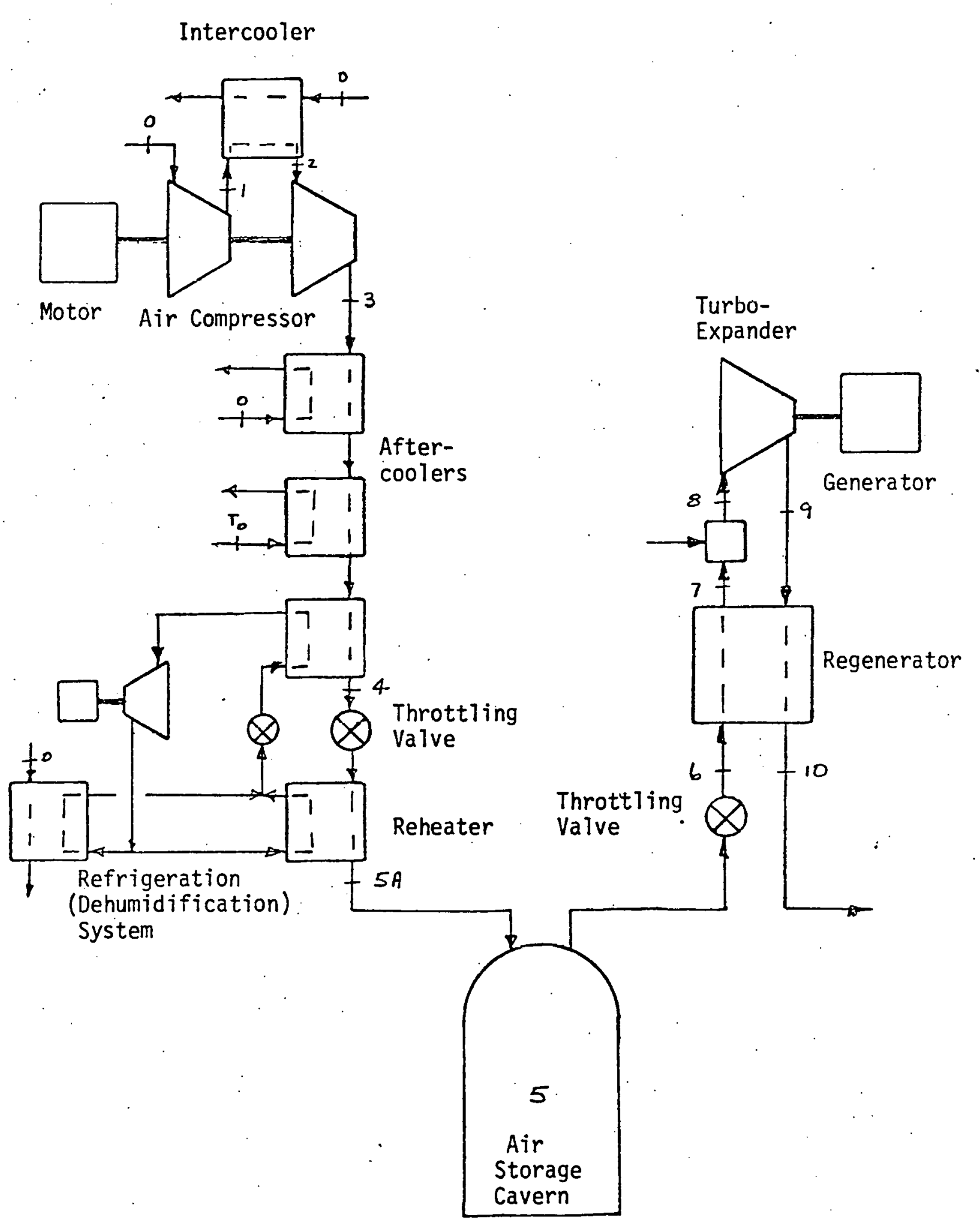

FIGURE 5. SCHEMATIC DRAWING OF SYSTEM 1 
7. Regenerative heat exchanger (cold side).

8. Combustion chamber.

9. Turbo-expander driving an electric gencrator.

10. Regenerative heat exchanger (hot side).

Each component was assigned a typical value of efficiency or effectiveness as follows:

1. Compressors, $\eta=75 \%$

2. Intercooler, $\epsilon=80 \%, \Delta \mathrm{P} / \mathrm{P}=5 \%$

3. Aftercoolers - air-to-air, $\epsilon=60 \%, \quad P / P=5 \%$

- air-to-water, $\epsilon=80 \%$

- air-to-refrigerant, $\Delta \mathrm{T}_{\min }=17^{\circ} \mathrm{F}\left(9^{\circ} \mathrm{C}\right)$

4. Reheater - refrigerant-to-air, $\Delta \mathrm{T}_{\min }=20^{\circ} \mathrm{F}\left(11^{\circ} \mathrm{C}\right)$.

5. Regenerator, $\epsilon=80 \%, \Delta \Gamma / F=5 \%$

6. Turbo-expander, $\eta=80 \%$

7. Electric Generator, $\eta=95 \%$

The fuel is assumed to be natural gas. The ambient air conditions are typical of Carlsbad, New Mexico, as determined by an analysis of five years weather data.

Two sizes of systems have been considered: $100 \mathrm{MW}$ output and $20 \mathrm{MW}$ output (nominal values). The most significant design conditions and results are given below:

System 1A, $100 \mathrm{MW}$ (nominal)

$$
\begin{array}{ll}
\mathrm{P}_{3}=255 \mathrm{psia} & \left(1.76 \times 10^{6} \mathrm{~N} / \mathrm{m}^{2}\right) \\
\dot{\mathrm{m}}_{3}=1.71 \times 10^{6} 1 \mathrm{~b}_{\mathrm{m}} / \mathrm{hr} & \left(7.76 \times 10^{5} \mathrm{Kg} / \mathrm{hr}\right) \text { for } 55 \mathrm{hrs} / \mathrm{wk} \\
\mathrm{P}_{8}=133 \mathrm{psia} & \left(9.17 \times 10^{5} \mathrm{~N} / \mathrm{m}^{2}\right) \\
\mathrm{T}_{8}=1.9 .50^{\circ} \mathrm{F}\left(1066^{\circ} \mathrm{C}\right) & \\
\dot{\mathrm{m}}_{8}=1.71 \times 10^{6} 1 \mathrm{~b}_{\mathrm{m}} / \mathrm{hr} & \left(7.76 \times 10^{5} \mathrm{Kg} / \mathrm{hr}\right) \text { for } 55 \mathrm{hrs} / \mathrm{wk}
\end{array}
$$




$$
\begin{array}{ll}
\text { Power Input }= & 1.84 \times 10^{10} \mathrm{Btu} / \mathrm{wk} \\
& (98 \mathrm{MW} \text { for } 55 \mathrm{hrs} / \mathrm{wk}) \\
\text { Power Output }= & 2.02 \times 10^{10} \mathrm{Btu} / \mathrm{wk} \\
& (108 \mathrm{MW} \text { ave rage for } 55 \mathrm{hrs} / \mathrm{wk}) \\
\text { Fuel Consumption }=\quad & 1.25 \times 10^{7} \mathrm{1b} / \mathrm{wk}=2.77 \times 10^{7} \mathrm{scf} / \mathrm{wk} \\
& (8400 \mathrm{scfm} \text { for } 55 \mathrm{hrs} / \mathrm{wk}) \\
& \left(2.63 \times 10^{10} \mathrm{Btw} / \mathrm{wk} \mathrm{based} \mathrm{on}\right. \\
& \mathrm{LHV}=21,000 \mathrm{Btu} / \mathrm{lb})
\end{array}
$$

System 1B, $20 \mathrm{MW}$ (nominal)

$$
\begin{aligned}
& P_{3}=160 \text { psia } \quad\left(1.10 \times 10^{6} \mathrm{~N} / \mathrm{m}^{2}\right) \\
& \dot{\mathrm{m}}_{3}=3.75 \times 10^{5} \mathrm{lb} / \mathrm{hr} \quad\left(1.70 \times 10^{5} \mathrm{Kg} / \mathrm{hr}\right) \text { for } 56 \mathrm{hrs} / \mathrm{wk} \\
& \mathrm{P}_{8}=128 \text { psia } \quad\left(8.83 \times 10^{5} \mathrm{~N} / \mathrm{m}^{2}\right) \\
& \mathrm{T}_{8}=1600^{\circ} \mathrm{F}\left(871^{\circ} \mathrm{C}\right) \\
& \dot{\mathrm{m}}_{8}=4.20 \times 10^{5} \mathrm{lb}_{\mathrm{m}} / \mathrm{hr} \quad\left(1.91 \times 10^{5} \mathrm{Kg} / \mathrm{hr}\right) \text { for } 50 \mathrm{hrs} / \mathrm{wk} \\
& \text { Power Input }=\quad 3.19 \times 10^{9} \mathrm{Btu} / \mathrm{wk} \\
& \text { (16.7 MW for } 56 \mathrm{hrs} / \mathrm{wk} \text { ) } \\
& \text { Power Output }=\quad 3.31 \times 10^{9} \mathrm{Btu} / \mathrm{wk} \\
& \text { (22. } 3 \mathrm{MW} \text { average for } 50 \mathrm{hrs} / \mathrm{wk} \text { ) } \\
& \text { Fuel Consumption }= \\
& 2.31 \times 10^{5} 1 \mathrm{~b} / \mathrm{m} / \mathrm{wk}=5.12 \times 10^{6} \mathrm{scf} / \mathrm{wk} \\
& \text { (1520 scfm for } 56 \mathrm{hrs} / \mathrm{wk} \text { ) } \\
& \left(4.85 \times 10^{9} \mathrm{Btu} / \mathrm{wk}\right. \text { based on } \\
& \mathrm{LHV}=21,000 \mathrm{Btu} / 1 \mathrm{~b}_{\mathrm{m}} \text { ) }
\end{aligned}
$$

The transient variation of pressure in the cavern is shown in Figure 6 for the two sizes. For eithe $r$ case, the temperature in the cavern remains constant within $\pm 3^{\circ} \mathrm{F}\left( \pm 2^{\circ} \mathrm{C}\right)$ and the relative humidity of the air in the cavern remains constant within \pm 18 percent.

Work is progressing with the analysis of System 2, which is basically a $25 \mathrm{MW}$ (nominal) turbo-expander operating with inlet conditions of 500 psia $\left(3.45 \times 10.6 \mathrm{~N} / \mathrm{m}^{2}\right)$ and $750^{\circ} \mathrm{F}\left(399^{\circ} \mathrm{C}\right)$. This system is being considered since it could be implemented using readily available, standard machine elements, whereas the gas turbine elements in System 1 are not currently available but would require redesign and modification of existing, standard designs. 


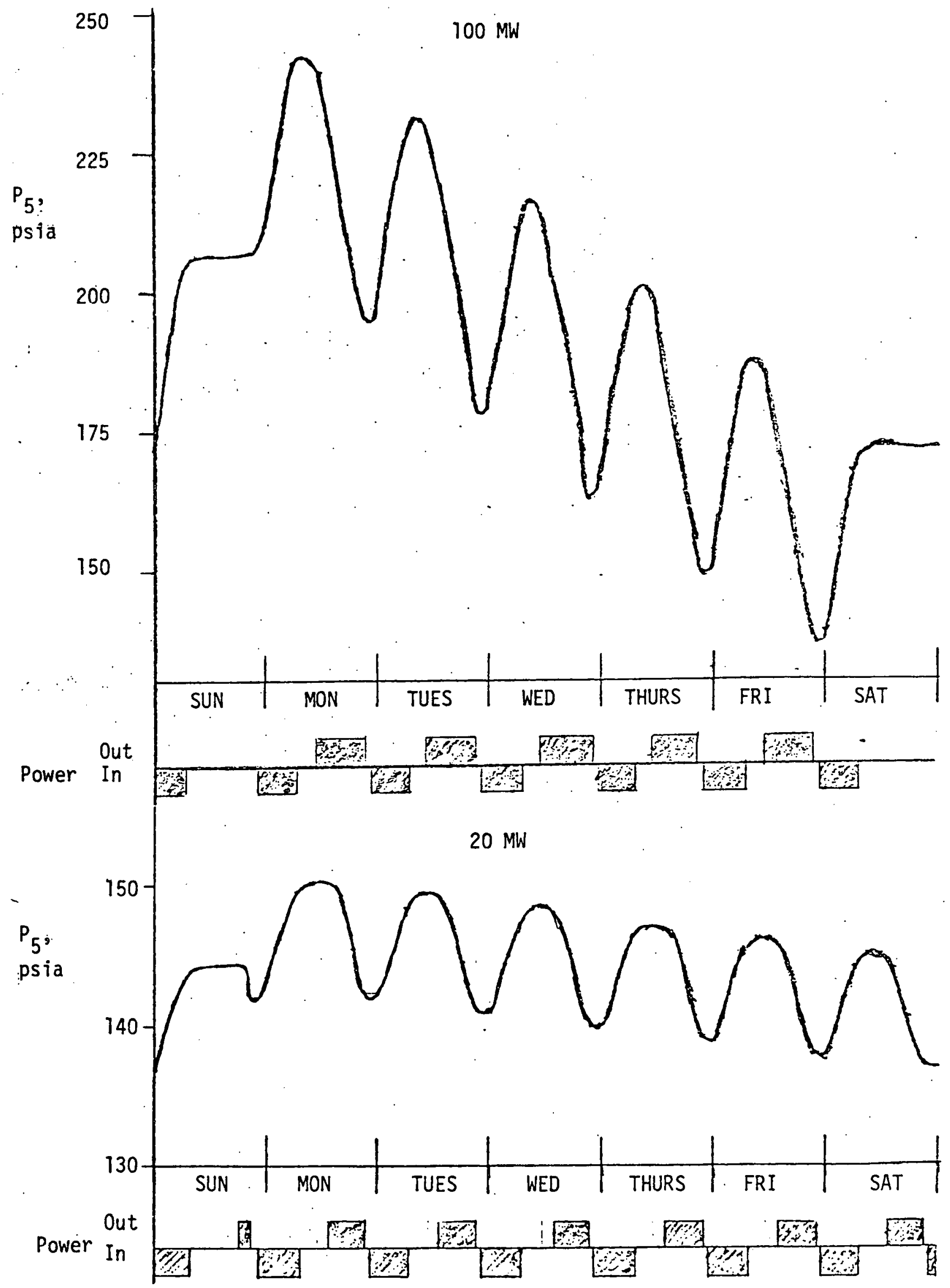

FIGURE 6. CAVERN PRESSURE VS. TIME 
IV. COST GOAL DETERMINATION TASK

Work on this task has been initiated. A task conference was held at Southwestern Public Service Company on 14 October to define the subtasks and to select base values. Results of the wind assessment study will be used to determine the cost goals for unfirmed systems. For convenience in calculation, a unit rating of one megawatt will be assumed.

For firmed systems, the results of the compressed air storage task for two system sizes (100 MW and $25 \mathrm{MW})$ and relevant charge-discharge characteristics will be used to determine the costs of a bench-mark conventional system. The most competitive of all conventional systems is selected to be a combined-cycle gas turbine-steam plant. 
V. TECHNICAL AND OPERATIONAL REQUIREMENTS TASK

The work reported here was performed by the Engineering Department of Southwestern Public Service Co.

A. General Wind-Generating Plant Requirements

In order to be of use as commercial generating stations, windgencrator systems must meet certain general, as well as specific requirements. In the first category are those items dealing with utility operating practice, maintenance, and service. These are:

1. The wind-generator unit should be arranged with all controls in a control house at ground level for convenient access of operating personnel.

2. Hoisting equipment should be designed into the tower to permit removal of the wind turbine or the generator and other machinery from the tower, as required for repair or maintenance. (Mobile cranes with sufficiently long booms for a unit of this height are not readily available and would increase the cost and downtime associated with repairs.)

3. The proposed plant site should be protected with adequate fencing to insure against the intrusion of unauthorized persons, both for the protection of the public and of the wind-generator equipment.

4. Site locations should be selected such that in the remote event of a tower collapse, due to tornado or other destructive occurrence, the property of other parities would not be damaged.

5. Sites should be chosen so that the location of several turbines within minimum distance is possible.

6. The wind-generator unit and its supporting tower should be designed for wind velocities of at least 120 miles per hour with 2 in. of ice'loading without damage.

7. It has been suggested that TV interference may be one of the most difficult obstacles to circumvent. This observation comes from the fact that a low-flying propeller-driven aircraft does cause significant and distinctive TV interference (although in this case only for a short time duration). It is likely that a wind turbine could cause a similar interference. If study indicates this to be the case, site selection must include consideration of this fact. 


\section{B. Electrical Requirements}

Due to the large physical nature of the WPG, and further assuming a small generator size of $1500 \mathrm{KW}$ or less, a suitable location is certainly rural. To economize on maintenance facilities, routine inspections, metering, control, etc., it would be desirable to locate a number of units in close proximity. For single units the degree of control and protection would necessarily, for economic reasons, be at lower level than for a group of machines, particularly of larger unit sizes. For large systems of many such units, supervisory control for monitoring operation of units may be justified. One might envision a mini-power park somewhat according to the attached diagram, Figure 7.

\section{Distribution Circuit Tie-In}

Consider a WPG, either singly or in a group, feeding into a rural distribution circuit of $12.5-\mathrm{KV}$ to $34-\mathrm{KV}$ rating. The wire size probably will be between \#2Al to \#4/0AGSR. The.circuit may or may not be shielded. The operating parameters of the distribution circuit must be considered critically. It is a small system in itself, tuned to accommodate a certain load cycle, load distribution along the line, and allowable voltage regulation limits combined with a voltage gradient along the line. Fault clearing and reclosing apparatus is carefully coordinated. The refore connecting a WPG into the distribution circuit could sreatc a complex set of variable operating conditions. A detailed study will be required for each proposed location to establish and/or define specific problems and operating limits of the distribution facilities, as well as to determine the maximum capacity of WPG that can be accommodated, probably in the range of 3000 to $5000 \mathrm{KVA}$. In some cases the complexity of the ope rating conditions, togethe $r$ with the additional circuit monitoring equipment, may eliminate the feasibility of adding WPG to an existing distribution circuit. In this event a separate distribution class line from the WPG to the distribution substation may be the better and simpler choice.

\section{Sub-Transmission Circuit Tie-In}

The alternative to a distribution voltage tie from the WPG to the utility system is a tie into the sub-transmission system. This would be a particularly attractive arrangement whe re a group of generators of 10 - to 15-MW total capability is contemplated. This arrangement offers advantages in operational control and monitoring, communication facilities, maintenance, inspection and security. Also it may present certain advantages to the research and study phase in that different designs, control systems, etc., could be concentrated at one location. Moreover, potential distribution system stability problems may be avoided. 


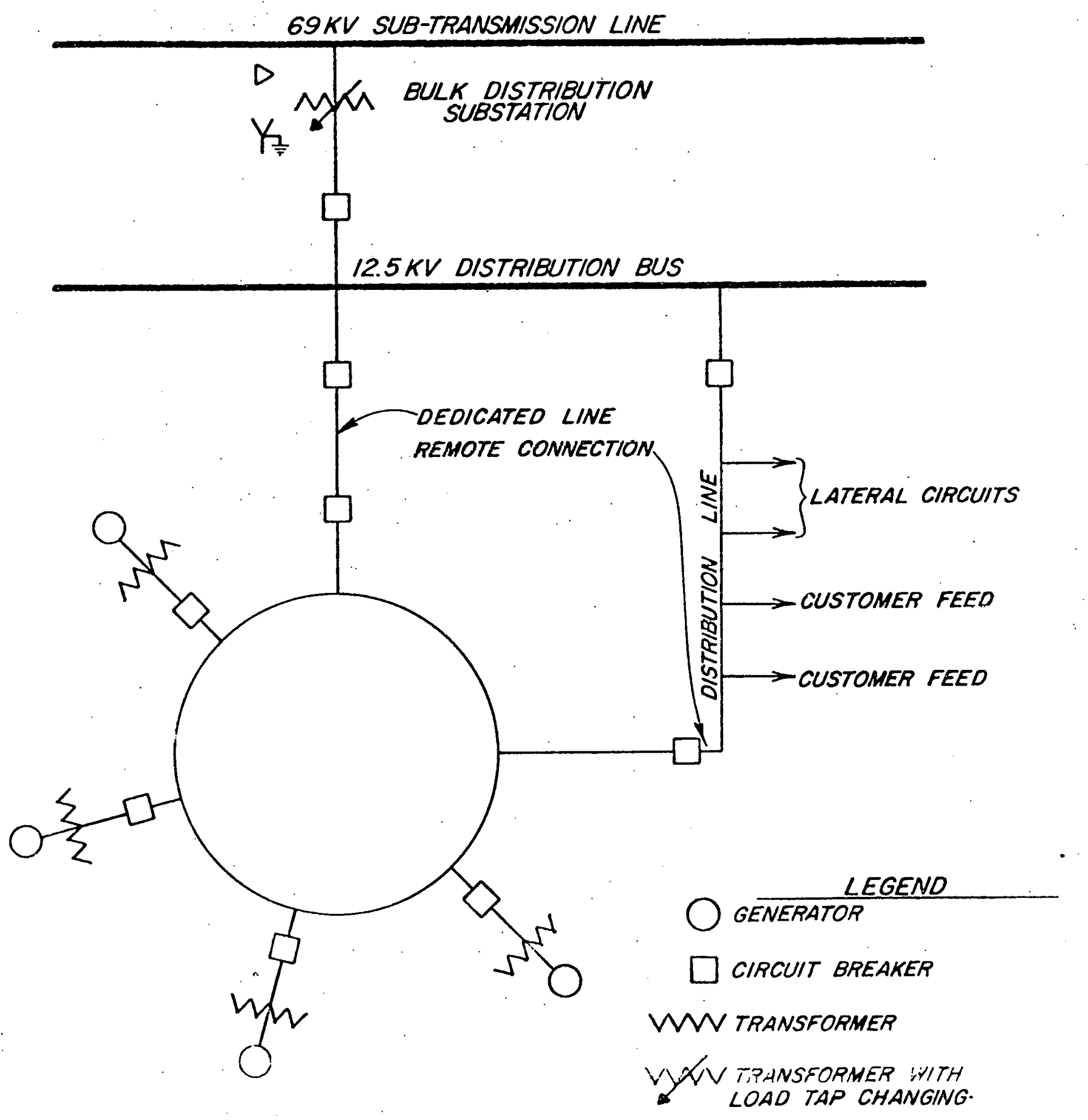

FIGURE 7. PROPOSED ELECTRICAL LAYOUT FOR CONNECTING WIND POWERED GENERA TORS TO AN ELECTRICAL UTILITY SYSTEM. 
Assuming that conventional AC electrical generators are employed, and that they are clustered together at one location, then all of the usual site-specific studies must be conducted to determine performance under abnormal conditions. The end result must produce a design for (1) a coordinated protective relaying system and (2) generators and excitation systems designed to produce electrically stable operation under steady-state and transient system conditions for all non-feathered WPG operating conditions.

If non-conventional generators are considered, such as direct current generators, or non-synchronous high-frequency generators, many new and interesting possibilities are presented. However, the end design must be capable of integrating into the utility electric system in a stable and controllable manner. The matter of cost of the se unconventional systems is a source of concern.

\section{Control Reguirements}

Individual wind-generating plants must be designed for completely automatic, fail-safe, unattended operation. The controls should include variable pitch or other speed control to enable automatic synchronizing of the generating unit to the electrical system, and should include a synchroaccepter to protect against malfunction of the auto synchronizer.

Voltage-regulating equipment should have provisions for automatic voltage matching to the system voltage at the time of sunchronizing. In addition, fluctuations of voltage caused by starting, stopping and powe $r$ changes produced by wind gusting, must be limited in magnitude and frequency to minimize the annoyance of incandescent lighting flicker.

For synchronous generators, it would be desirable that speed control be capable of maintaining frequency within \pm 0.5 cycles of 60 cycles with the wind generator running isolated from the utility company's electrical system.

Hourly readings of kilowatt hours gene rated could be transmitted to a remote point for recording, and instantaneous values of watts and vars could be available to remote control center personnel on demand for the larger systems, but cost would be a determining factor.

It is most desirable that the wind-generating unit be designed to operate over as wide a range of wind velocities as possible to minimize the number of separations and resynchronizing operations, to minimize disturbances to the system and to maximize generated energy. 
Protective monitoring of variables such as unit vibration, bearing temperature, hydraulic control pressures, etc., in addition to electrical values such as volts, amps, and excitation should be included and alarmed where necessary. These protective realy operation and alarm conditions should be indicated at a remote control center of the utility company through supervisory control circuits, if justified by plant capacity.

Data logging and recording equipment located at the windgenerator site should be designed for operation unattended for periods of at least one week or longer without intervention by an operator for chart replacement, etc. It would appear desirable to include wind data as well as unit performance in the operating records.

Because of the size and location of WPG, lightning protection will be necessary, including low tower grounding resistance, arresters, and undoubtedly shielding as well.

D. Maintenance and Spare Parts Requirements

Careful consideration should be given in the design of a WPG to provisions for maintenance with a minimuiı of people. Suitable means of access, working platforms and hoisting equipment are very important.

Rapid availability of repair parts will shorten the duration of unit outages and improve the utilization of the available wind energy. This will be a highly significant item in overall cost analysis. 


\section{INSTITUTIONAL CONSIDERATIONS TASK}

Texas has an unusually favorable regulatory climate for the development of new energy sources, including windpower systems. With the exception of nuclear plants, for which the requirements have been set by the Federal Government, there are no regulatory agencies with direct cognizance of utility plant construction in the State. Only within the past legislative session has Texas provided for a Utilities Commission.

Typically, a privately owned electric utility in Texas is responsible. only to local rate setting bodies, and to its financial sources. Municipally controlled utilities generally operate in a similar manner, responsible to a governing body analogous to a board of directors, under varying degrees of control of municipal authorities, who must authorize the issuance of bonds and, in some cases, approve new construction. Control of all electric utilities in the State is largely limited to the rate structure, in which public interest is balanced against legal recognition of an allowable rate of return on investment.

At the Federal level, the Federal Power Commission and the Securities and Exchange Commission accounting and reporting requirements apply to interstate utilities. Most of Texas' intrastate utilities choose to operate within FPC and SEC guidelines which are not generally restrictive, certainly not in the matter of power sources. The Federal Energy Administration now has broad powers in the fuel supply area, most of which have not yet been excercised on any but an emergency basis. Even prior to FEA Texas utilities fuel gas suppliers limited and curtailed electric utility fuel use by exercise of the interruptible clauses in supply contracts.

There are no general requirements in Texas that bind a utility to obtain approval from any environmental authority for siting or construction of a particular type of power plant, other than those requiring nuclear fuel. State and Federal regulations limit air and water pollution, but with the exception of nuclear plants these requirements have not acted to prevent the construction or operation of new generating facilities. Zoning restrictions are within the powers of municipal and county governments in Texas; however, since most generating facilities are located outside of municipal limits, only county zoning restrictions apply and these are easily satisfied in most cases.

Much more restrictive are the requirements of good business practice, for which the utility must answer to its stockholders and financial sources. These, of course, have to do with the rate of return on investment and the 
general ability of the utility to meet its financial obligations. At the present time there is nothing within State or Federal statutes that would proscribe Southwestern Public Service Co. (or any other Texas utility) from installing several megawatts, or even several hundred megawatts of wind generator plant capacity if it was economically justified and if funds could be made available. Certainly no responsible utility could expand windpower plants to include a sizeable share of total generating capacity without long-term experience, and hard proof that such installations would be both technically and economically viable.

Implementation of wind generator systems funded by the Federal Government, poses the added statutory requirement for the filing of environmental impact statements. This can be as serious as the Courts allow it to be. There are at least 31 identifiable Federal agencies having some area of jurisdiction or special interest in environmental matters, under certain circumstances. Probably all or most a re eager to as sume regulatory authority over anything, including wind generators. Most of their connection to windpower is farfetched, but some could be troublesome. The Environmental Protection Agency, the Federal Energy Administration and the Federal Aviation Administration are among those certain to at least take note of wind conversion machines, and a number of others are vaguely connected through reference to "land use and management". The latter cover a range of agencies from the Bureau of Land Management of the Department of the Interior, to the Bureau of Outdoor Recreation, the National Park Service and the Bureau of Reclamation.

There are sixteen state agencies in Texas having some jurisdiction or official interest in either environmental protection or land use and management. These range from the Texas Air Control Board, through the Environmental Protection Division of the Texas Attorney. General's Office, all the way to the Texas Antiquities Committee. Many of these are merely advisory bodies (e.g., the Energy Resources Council of the Office of the Governor) and one, the newly formed Itilities Cornmission, has not yet had its duties fully defined. The most experienced and powerful regulatory body in the State, the Texas State Railroad Commission, has for years been both the principal representative of the petroleum industry in the $S$ tate, and its regulatory and control body. That Commission now has a "Renewable Resources Department" which easily could stand first in line before the State Legislature, to accept any jurisdictional control that may develop over windpower at the state level. This is particularly the case should some question arise about the ownership of the energy in the wind above a land area. 
Whatever the regulatory impact at the State level turns out to be, it will more than likely involve questions of land use. Compared with other generating systems, the land requirement for siting large wind generator systems (likely in the range of from one to five acres/megawatt) together with access roads and transmission line rights of way, would appear to be reasonable. The difficulty is likely to arise in the number of individual. sites required. If it becomes necessary to site one windmill on five acres in each square mile of land area, for example, land procurement may become such a troublesome matter as to preclude large scale implementation. The experience of the pipeline industry in Texas indicates that land requirements can generally be met only through condemnation proceedings. Condemning the large number of small plots of land required to implement several hundred megawatts of wind generators, is likely to provide a formidable task compared to the return. However, existing generating plant and substation sites and transmission line rights of way could accommodate a certain number of wind generating units. Beyond that, questions of wind energy captured from adjacent property could conceivably lead to a system of leasing "wind rights" over a sizeable area of land.

Probably the most valuable lesson to be learned by ERDA and all those involved in energy matters is available in the example posed by the California geothermal situation. Eagerness to jump on the regulatory bandwagon, by both State and Federal authorities, has effectively strangled that fledgeling industry, bcfore it really began. 